Економічні науки: збірник наукових праџь Луцького національного технічного університету. - Серія "Регіональна економіка". - Випуск 16 (63). - Редкол.: відп. ред. д.е.н., професор Л.Л. Ковальська - Луцьк : ІВВ Луцького НТУ, 2019. -173 с.

УДК $331.101 .2(477): 351.77$

Шубалий О.М., д.е.н., професор

Зімич Р.В.

Луцький національний технічний університет

\title{
ТЕНДЕНЦІЇ ЗМІНИ ТА НАПРЯМИ ПОКРАЩЕННЯ КАДРОВОГО ЗАБЕЗПЕЧЕННЯ СФЕРИ ОХОРОНИ ЗДОРОВ'Я УКРАЇНИ
}

У статті вивчено тенденції зміни та обгрунтовано напрями покращення кадрового забезпечення сфери охорони здоров’я України.

Ключові слова: охорона здоров'я, кадрове забезпечення, медичні кадри, лікарі, країна.

Shubalyi O.M. Zimych R.V.

\section{TRENDS OF CHANGE AND DIRECTIONS FOR IMPROVING THE STAFFING OF HEALTH CARE IN UKRAINE}

The purpose of the study is to study the trends of change and justify the directions of improvement of human health care in Ukraine.

Trends in changes in key indicators of health care provision at the state level reflect changes in the health situation as a whole. This has a negative impact on student enrollment and the number of health care professionals trained, and the qualification of existing staff, which cannot in the long run affect the decline in the number and quality of medical services provided. Improvement factors include raising the level of remuneration for junior and secondary medical staff, especially physicians, to review the remuneration system for highly qualified and highly specialized doctors. Create a system of accruals and payments of periodic additional payments in the form of bonuses. Improve provision of specialized offices with technological equipment. There is an acute shortage of medical staff in rural areas, caused by a lack of funds from local communities to pay salaries and retention of midwives.

The high dispersion of villages and the lack of proper transport communication and the lack of high-quality wireless connectivity create problems for assisting family practitioners who cannot be addressed by health care. A significant outflow of highly qualified doctors and nursing staff is mainly from rural areas, which is a major problem, mainly in Poland and Western Europe, also caused by low salaries and by the governments of these countries in attracting staff from developing countries.

The purpose of compulsory future employment, both voluntary and involuntary, is not intended in the training of medical personnel, although this 
Економічні науки: збірник наукових праџь Луцького національного технічного університету. - Серія "Регіональна економіка". - Випуск 16 (63). - Редкол.: відп. ред. д.е.н., професор Л.Л. Ковальська - Луцьк : ІВВ Луиького НТУ, 2019. - 173 с.

practice is very effective for students studying under the government order, it will reduce the number of medical personnel traveling abroad.

It is recommended to create a nationwide program with funding from a separate item of health care costs for internships abroad, which will allow them to gain new practical experiences and specific skills, see effective change abroad, and try to apply them to us. Further deterioration of the health sector's staffing situation is not replaced by positive trends, although it is significantly slowed down by a slight increase in salaries, except for non-family practitioners who have their own conditions, and the elimination of staff positions that have been poorly designed and ineffectively fulfilled. within the framework of medical assistance and counseling services. The problem of ambulance arises first of all in the nature of ignorance of the population, the cause of which is the overwhelming majority of calls to doctors, which were not urgent and sometimes necessary at all. This can be addressed through the creation of a television program to improve the health literacy of the population, and in the future will greatly reduce unnecessary waste of time and material resources that could be diverted to measures to improve staffing of medicine. The problem of self-treatment of Ukrainians often leads to greater consequences of the disease and an increase in the duration and cost of treatment, while ignoring the foreseen opportunity to undergo a medical examination and consult a qualified doctor.

Key words: health protection, staffing of health care, medical personnel, doctors, country.

\section{Шубалый А.М., Зимич Р.В. \\ ТЕНДЕНЦИИ ИЗМЕНЕНИЯ И НАПРАВЛЕНИЯ УЛУЧШЕНИЯ КАДРОВОГО ОБЕСПЕЧЕНИЯ ЗДРАВООХРАНЕНИЯ УКРАИНЫ}

В статье изучено тенденции изменения и обоснованы направления улучшения кадрового обеспечения сферы здравоохранения Украины

Ключевые слова: здравоохранение, кадровое обеспечение, медицинские кадры, врачи, страна.

Постановка проблеми у загальному вигляді і ії зв'язок 3 важливими науковими та практичними завданнями.

Постановка питання ефективності діяльності закладів охорони здоров'я в розрізі надання медичних послуг в першу чергу відноситься до кількості та якості кадрів, що відноситься до кадрового забезпечення сфери охорони здоров'я України, перед яким стоїть завдання розробки кадрової стратегії, підготовки найму та утримання кадрів медичної сфери. 
Економічні науки: збірник наукових праиь Луиького національного технічного університету. - Серія "Регіональна економіка". - Випуск 16 (63). - Редкол.: відп. ред. д.е.н., професор Л.Л. Ковальська - Луцьк : ІВВ Луиького НТУ, 2019. - 173 с.

Задовільнення їхніх потреб в умовах праці та створення способів адекватної оплати праці відповідно обсягів наданої допомоги. При недостатній увазі до проблем охорони здоров'я виникає відтік молодих та досвідчених кадрів що спричиняє неукомплектованість медичних посад. Для детального вивчення проблем охорони здоров'я розглянемо тенденції показників в масштабах України

Аналіз останніх досліджень, у яких започатковано вирішення проблеми. Теоретичні дослідження сутності та вивчення проблем кадрового забезпечення проводили велика кількість вчених, в тому числі: Дарміць Р.3., Горішна Г.П., Грішнова О.А., Жорова Є.Р, Кагановська Т.Є., Котельникова Ю.М, Дембілька С., Лазоренко Л.В, Клочко А.М., В.Ф. Золотарьов, Скібіцька Л.І., Скібіцький О.М., B.M. Колпаков $[5,6]$, частина яких проводилась в різних періодах, що свідчить про тривалий час нарощення існуючих проблем та відсутність суттєвих заходів для їх вирішення

Цілі статті. Метою статті є дослідження динаміки зміни показників та обгрунтування напрямів покращення кадрового забезпечення сфери охорони здоров' я України.

Виклад основного матеріалу дослідження 3 повним обгрунтуванням отриманих наукових результатів. Існуюче кадрове забезпечення сфери охорони здоров'я України дозволяє виконувати основні завдання покладені на цю галузь 3 проведення заходів щодо попередження, надання невідкладної медичної допомоги, лікування, консультацій задля одужування та профілактики порушення здоров'я громадян країни, проводячи заходи отримані при професійній підготовці та здобуті протягом тривалого досвіду, що дозволяє зберігати можливості до праці іншими професійними групами населення та збагачувати цінностями суспільство реалізовуючи свій трудовий потенціал.

Кадрове забезпечення - це процес виконання управлінських функцій з метою задовільнення потреб в кадрах, 
Економічні науки: збірник наукових праџь Луцького національного технічного університету. - Серія "Регіональна економіка". - Випуск 16 (63). - Редкол.: відп. ред. д.е.н., професор Л.Л. Ковальська - Луцьк : ІВВ Луцького НТУ, 2019. -173 с.

шляхом навчання, підготовки, набору, визначення їхніх відносин в робочому середовищі, проведення їх оцінки, розробка методів навчання та підвищення кваліфікації, визначення потенціалу та подальший перерозподіл в сфері охорони здоров'я використовуючи новітні технології пошуку, збалансування та управління кадрами.

На якість виконання функцій установами охорони здоров'я найбільше впливає якість підготовки медичних кадрів що виражається в професійності виконуваної праці, ефективності реалізації потенціалу та якості лікування при застосуванні новітніх технологій, поєднанні новітніх методів та досвіду. Виконавча структура управління охорони здоров'я включає кабінет міністрів, міністерство охорони здоров'я, обласні управління та місцеві ОТГ. Важливим фактором в сфері охорони здоров'я виступає територіальне розміщення закладів та кадрів сфери охорони здоров'я, їх структурнокваліфікаційний склад та розподіл по населенню країни. Детальніший розгляд характеристики охорони здоров'я відображений в таблиці 1.

Таблиця 1

Заклади та кадри сфери охорони здоров'я України

\begin{tabular}{|c|c|c|c|c|c|c|c|c|c|}
\hline \multirow{3}{*}{ Покизиники } & \multirow{3}{*}{2016} & \multirow{3}{*}{2017} & \multirow{3}{*}{2018} & \multicolumn{6}{|c|}{ Відхилення } \\
\hline & & & & \multicolumn{2}{|c|}{$2017 / 2016$} & \multicolumn{2}{|c|}{ 2018/2017 } & \multicolumn{2}{|c|}{$2018 / 2016$} \\
\hline & & & & абс & відн & абс & абс & відн & абс \\
\hline $\begin{array}{l}\text { Всього лікар- } \\
\text { няних закладів }\end{array}$ & 1743 & 1714 & 1671 & -29 & $-1,66$ & -43 & $-2,51$ & -122 & $-6,80$ \\
\hline $\begin{array}{l}\text { лікарів на } 10 \\
\text { тис. населення }\end{array}$ & 44 & 44,1 & 44,2 & 0,1 & 0,23 & 0,1 & 0,23 & 0,7 & 1,61 \\
\hline $\begin{array}{l}\text { \% осіб пенсій- } \\
\text { ного віку }\end{array}$ & 24,1 & 24,5 & 24,6 & 0,4 & 1,66 & 0,1 & 0,41 & 0,3 & 1,23 \\
\hline $\begin{array}{lr}\text { середнього } \\
\text { персоналу на } \\
10 & \text { тис. } \\
\text { населення } & \end{array}$ & 86,5 & 85,4 & 82,3 & $-1,1$ & $-1,27$ & $-3,1$ & $-3,63$ & $-6,3$ & $-7,11$ \\
\hline $\begin{array}{l}\% \text { осіб пенсій- } \\
\text { ного віку }\end{array}$ & 13 & 12,9 & 12,7 & $-0,1$ & $-0,77$ & $-0,2$ & $-1,55$ & -1 & $-7,30$ \\
\hline
\end{tabular}

Примітка. Складено автором на основі джерела [1] 
Економічні науки: збірник наукових праџь Луцького національного технічного університету. - Серія "Регіональна економіка". - Випуск 16 (63). - Редкол.: відп. ред. д.е.н., професор Л.Л. Ковальська - Луцьк : ІВВ Луцьккого НТУ, 2019. -173 с.

Згідно аналізу таблиці, в 2018 році кількість закладів скоротилась на $43(-2,51 \%)$ в порівнянні з 2017 роком, а в 2017 році в порівнянні з 2016 роком на 29 закладів (-1,66\%), різниця між 2018 та 2016 роком 122 заклади (-6,80\%). Тобто кількість закладів поступово скорочується. Забезпеченість населення лікарями на 10 тисяч в 2018 році склала 44,2 осіб, що є на $0,23 \%$ більше ніж в 2017 році та 1,61\% більше ніж в 2016 році, а різниця між 2017 та 2016 роком становить $0,23 \%$. В цілому при скороченні закладів охорони здоров'я забезпеченість на 10 тисяч населення лікарями поступово зростає, а середнього медичного персоналу скорочується. Кількість пенсіонерів зростає серед лікарів, а середнього персоналу падає.

Для розуміння ресурсів сфери охорони здоров'я важливо розглянути фінансування сфери охорони здоров'я що дозволить визначити наочну увагу до цілої сфери та іiї проблем. Для цього розглянемо видатки в таблиці 2.

Таблиця 2

Зростання видатків державного бюджету України на охорону здоров’я за 2014-2018 роки

\begin{tabular}{|c|c|c|c|c|c|}
\hline $\begin{array}{c}\text { Показники } \\
\text { Роки }\end{array}$ & $\begin{array}{c}\text { Зростання } \\
\text { всього } \\
\text { видатків } \\
\text { ДБУ, \% }\end{array}$ & $\begin{array}{c}\text { Зростання } \\
\text { видатків } \\
\text { ДБУ, \% }\end{array}$ & $\begin{array}{c}\text { Зростання } \\
\text { Загально- } \\
\text { держ. } \\
\text { видатків, \% }\end{array}$ & $\begin{array}{c}\text { Зростання } \\
\text { всього, } \\
\text { млрд грн } \\
\text { видатків на } \\
\text { О3 у } \\
\text { видатках } \\
\text { Зведеного } \\
\text { бюджету } \\
\text { України }\end{array}$ \\
\hline $2015 / 2014$ & 36,20 & $-27,27$ & $-4,26$ & $-8,62$ & 10,9 \\
\hline $2016 / 2015$ & 20,26 & 12,50 & 0,00 & 1,89 & 10 \\
\hline $2017 / 2016$ & 18,70 & 44,44 & 26,67 & 29,63 & 8,3 \\
\hline $2018 / 2017$ & 18,23 & 76,92 & 3,51 & 17,14 & 9,1 \\
\hline $2018 / 2014$ & 129,87 & 109,09 & 25,53 & 41,38 & 9 \\
\hline
\end{tabular}

Примітка. Складено на основі джерел [2-3] 
Економічні науки: збірник наукових праџь Луцького національного технічного університету. - Серія "Регіональна економіка". - Випуск 16 (63). - Редкол.: відп. ред. д.е.н., професор Л.Л. Ковальська - Луцьк : ІВВ Луцьккого НТУ, 2019. -173 с.

Згідно таблиці 2 та рисунку 1 найбільші видатки на охорону здоров'я зі зведеного бюджету України складали 82 млрд. грн у 2018 році, що є на 17,14\% більше ніж в 2017 році, приріст між 2016 і 2017 роками 29,63\%, менший приріст між 2015 і 2014 роком 1,89\%, але найменший -8,62\% між 2015 та 2014 роком або 53 млрд. грн та 58 млрд. 168ол. відповідно. Приріст між 2018 та 2014 роками склав 41,38\%, тобто зростання $\epsilon$ досить значним, при тому що в абсолютних значеннях це $є$ 24 мільярди гривень, але зі зростаючою інфляцією це не $\epsilon$ позитивним показником. Згідно даних частки видатків на О3 у видатках зведеного бюджету України то найменші дані припадають на 2016 рік із показником 8,3\%, найбільше в 2014 році - 10,9\%, а в 2018 році $9,0 \%$.
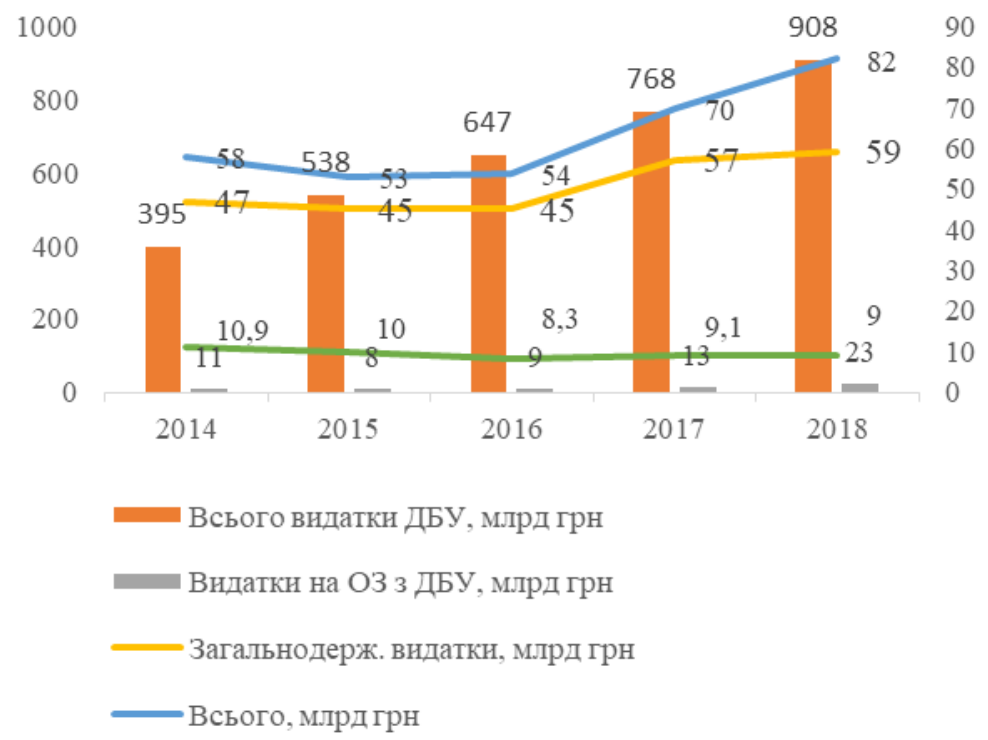

Рис. 1. Структура фінансування сфери охорони здоров'я 3 державного зведеного бюджету 2014-2018 рр. (складено автором на основі джерела [2-3] 
Економічні науки: збірник наукових праць Луиького національного технічного університету. - Серія "Регіональна економіка". - Випуск 16 (63). - Редкол.: відп. ред. д.е.н., професор Л.Л. Ковальська - Луцьк : ІВВ Луцького НТУ, 2019. -173 с.

Тобто існує тенденція поступового зменшення долі сфери охорони здоров'я в загальній структурі бюджету країни, що в подальшому обов'язково відіб'ється в показниках здоров'я громадян нашої країни.

Згідно відомих тверджень, якщо доля витрат бюджету на охорону здоров'я нижче $15 \%$ то це є привід задуматися над збільшенням обсягів фінансування, адже це означає що існуюча система охорони здоров'я може лише частково виконувати свої обов'язки тому кадрове забезпечення сфери не зможе ефективним чином заохочувати нові кадри на підготовку для заміни існуючого кадрового складу та залишиться частина населення які втратили свою можливість отримати допомогу через брак ресурсів, а це в свою чергу потягне за собою зменшення показників якості життя, тому постраждають інші сфери економіки, адже скоротиться загальна відпрацьована кількість часу, а тому вклад в суспільство держави.

Для визначення впливу ВВП держави на кадрове забезпечення сфери охорони здоров'я розглянемо таблицю 3 та рисунок 2.

Таблиця 3

Зіставлення абсолютних показників номінального ВВП, лікарів та середнього медичного персоналу за 2016-2018 роки

\begin{tabular}{|l|c|c|c|c|c|c|}
\hline \multicolumn{1}{r|}{ Роки } & 2016 & 2017 & 2018 & \multicolumn{3}{|c|}{ Абсолютне відхилення } \\
\cline { 5 - 7 } Показники & & $2017-2016$ & $2018-2017$ & $2018-2016$ \\
\hline $\begin{array}{l}\text { Номін.ВВП, } \\
\text { млн., } \\
\text { США }\end{array}$ & 93270 & 112154 & 130832 & 18884 & 18678 & 37562 \\
\hline $\begin{array}{l}\text { Всього } \\
\text { лікарів }\end{array}$ & 186776 & 186178 & 185675 & -598 & -503 & -1101 \\
\hline $\begin{array}{l}\text { Середнього } \\
\text { медичного } \\
\text { персоналу }\end{array}$ & 366756 & 360416 & 345364 & -6340 & -15052 & -21392 \\
\hline
\end{tabular}

Примітка. Складено автором на основі джерела [4] 
Економічні науки: збірник наукових праџь Луцьького національного технічного університету. - Серія "Регіональна економіка". - Випуск 16 (63). - Редкол.: відп. ред. д.е.н., професор Л.Л. Ковальська - Луцьк : ІВВ Луцького НТУ, 2019. -173 с.

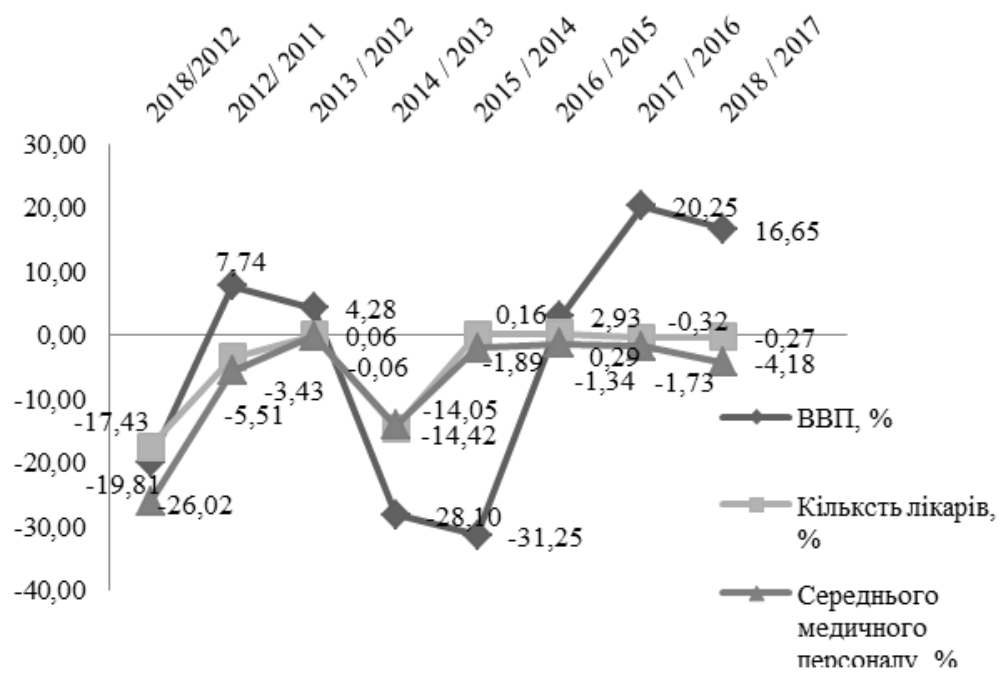

Рис. 2 Показники відносного зростання номінального ВВП, кількості лікарів та середнього медичного персоналу, \% за 2012-2018роки. (складено автором на основі джерела [4])

Згідно даних таблиці 3, при зростанні номінального ВВП між 2017 та 2016 роком на 18,884 млрд. дол. США. (20,25\% згідно рисунку 2), кількість лікарів скоротилась на 598 особи, $(-0,32 \%)$, середнього медичного персоналу -6340 особи $(-1,73 \%)$. Між показниками 2018 та 2017 року номінальний ВВП зріс на 18,678 млрд. дол. США (16,65\%), кількість лікарів скоротилась 503 особи (-0,27\%), а середнього медичного персоналу на 15052 осіб (-4,18\%). Номінальний ВВП між 2018 та 2016 роком зріс на 37,562 млрд. дол. США, хоча кількість лікарів зменшилась на 1101 особу, а середнього медичного персоналу $-1,34 \%$.

Висновки. В цілому останні дані характеристики сфери здоров'я свідчать про скорочення як кількості лікарняних закладів так і медичних кадрів так і сфери в цілому. Абсолютні та відносні показники забезпеченості кадрами сфери охорони здоров'я падають, що свідчить про значні проблеми в сфері 
Економічні науки: збірник наукових праџь Луцького національного технічного університету. - Серія "Регіональна економіка". - Випуск 16 (63). - Редкол.: відп. ред. д.е.н., професор Л.Л. Ковальська - Луцьк : ІВВ Луиького НТУ, 2019. - 173 с.

охорони здоров'я, як цілої системи так i кадрового забезпечення. Тому позитивна зміна показників забезпеченості лікарів на 10 тисяч населення (табл. 1) свідчить не про збільшення кількості лікарів (табл. 2) а про негативний природний рух чисельності населення, а кількість середнього медичного персоналу скорочується, що свідчить про відсутність мотивації, можливі некомфортні умови праці, та дуже незадовільна заробітна плата, що стосується як самого окладу так і відсутності додаткових виплат та матеріальних винагород.

Скорочення кількості лікарів в перший рік збільшення кількості штатних посад в рамках сімейної медицини свідчить про недосить вдалий початок реформи, що $\epsilon$ причиною нераціонального поділу посад, неправильного розподілу лікарів по штатним посадам, незадоволеність участі лікарів які відносяться до вузькоспеціалізованих напрямів високої кваліфікації.

Сьогоднішня тривала економічна ситуація в сільській місцевості не дозволяє отримувати гідну заробітну плату, що довгий час вимиває середній медичний персонал із сільської місцевості. Ситуація сімейних лікарів дещо інша, адже при складанні більше половини квоти договорів, досягається хороше матеріальне забезпечення в порівнянні 3 іншими професіями. Але проблема зарплати залишається при малих селах та великою віддаленістю між ними.

Найважливішим завданням задля покращення кадрового забезпечення сфери охорони здоров'я $€$ створення стратегії подальшого вдосконалення з приорітетним статусом в рамках підготовки кадрів: покращення програм освіти, створення в державних банках програм під тривале кредитування вартості навчання та проживання з низьким відсотком студентів-медиків, приватним закладам освіти надати можливість повністю самостійно складати навчальні програми у відповідності до помірно розвиваючого приватного ринку праці, створювати прив'язку державних місць до штатних посад установ охорони здоров'я. 
Економічні науки: збірник наукових праџь Луцького національного технічного університету. - Серія "Регіональна економіка". - Випуск 16 (63). - Редкол.: відп. ред. д.е.н., професор Л.Л. Ковальська - Луцьк : ІВВ Луцького НТУ, 2019. -173 с.

Також задля заохочення новачків медицини рекомендується встановити ставку оплати праці для інтернів хоча б на рівні мінімальної заробітної плати, що дозволить приводити менше зусиль на пошук засобів існування при відсутньому досвіді та можливості повноцінно працювати.

Реформа не передбачає підвищення зарплати сімейним лікарям за рахунок підвищення кваліфікації, таким чином атестація передбачає розвиток в рамках обов'язкових післяосвітніх формальних програм, а не власного саморозвитку.

1.Медичні кадри та мережа закладів охорони здоров'я системи МОЗ України за 2017-2018 роки/ Головний укладач Заболотько В.М. Київ: Центр медичної статистики МОЗ України, 2018. 66 с.

2.Руденко В.В. Сучасний стан фінансового забезпечення охорони здоров'я в Україні. Економіка $i$ суспільство. 2018. № 10. URL: http://economyandsociety.in.ua (дата звернення: 12.11.2019).

3.У 2018 році видатки на охорону здоров'я складуть понад 80 млрд грн. Ваша газета: веб-сайт. URL : http://yur-gazeta.com/golovna/u-2018-roci-vidatkividatki-na-ohoronu-zdorovya-skladut-ponad-80-mlrd-grn.html (дата звернення: 15.11.2019).

4.Валовий внутрішній продукт. Міністерство фінансів. : веб-сайт. URL : https://index.minfin.com.ua/ua/economy/gdp/2018/ (дата звернення: 30.10.2019).

5.Грішнова О.А. Кадрове забезпечення ефективної системи антикризового корпоративного управління Проблеми економіки. 2014. № 1. 193 c. URL: http://nbuv.gov.ua/UJRN/Pekon_2014_1_28 (дата звернення: 12.11.2019).

6.Котельникова Ю.М. Кадрове забезпечення управління підприємством. Економіка та управління підприємствами.2018. № 19. C. 201-208. 